\title{
New speaker parents as grassroots policy makers in contemporary Galicia: ideologies, management and practices
}

\section{Bernadette O'Rourke $^{1}$ (D) . Anik Nandi ${ }^{2}$}

Received: 7 November 2017 / Accepted: 22 November 2018 / Published online: 6 March 2019

(c) The Author(s) 2019

\begin{abstract}
This study examines the role of new speaker parents who have made a conscious decision to bring up their children in Galician, a language which they themselves did not acquire in the home. Although intergenerational transmission has for long been considered a crucial part of linguistic vitality, new speakers bring complexity to this paradigm and in particular prompt questions about their role as parents and as potential agents of sociolinguistic change in the process of language revitalization. Through their individual as well as collective linguistic practices, new speaker parents have the potential to generate visible and/or invisible language planning on the ground, influencing their children's language learning and creating future generations of speakers. As such, these parents, through their own linguistic behaviour, can play a potentially significant role in the revitalization and maintenance of Galician outside the school through their family language policies in the home. Drawing on two focus group discussions involving seven families in two of Galicia's urban centres, Santiago de Compostela and Vigo, we investigate how these new speaker parents exercise their agency and become policy makers in their homes.
\end{abstract}

Keywords Family language policy · New speaker parents · Language revitalization · Bilingualism · Galicia

Bernadette O'Rourke

b.m.a.o'rourke@hw.ac.uk

Anik Nandi

A.Nandi@qub.ac.uk

1 Heriot-Watt University, Edinburgh, UK

2 Queen's University, Belfast, UK 


\section{Introduction}

While language policy has been conventionally studied as a macro-level phenomenon, researchers have increasingly come to appreciate the importance of micro-level policy (Baldauf 2006), investigating the complex relationship between policy at macro- and micro-levels (see McCarty 2011; Ricento 2015). Rather than contrasting divides between 'top-down' and 'bottom-up' policies, there has in more recent years been an attempt to analyze how discourses circulate across and within the language policy cycle (Canagarajah 2006). As Johnson (2013) notes, there is now a growing interest in how social actors position themselves vis-à-vis such discourses as a means of opening up ideological spaces for the use or non-use of certain languages or linguistic varieties. This has shifted the focus in language policy research away from a macro-analysis of national policies to an understanding how such policies are interpreted, implemented and negotiated by social actors on the ground.

In this paper we examine how official language policies in contemporary Galicia are interpreted and negotiated by "new speaker" parents who have made a conscious decision to bring up their children in Galician, a language which they themselves did not acquire in the home. We use the term "new speakers" to refer to individuals who did not learn a (minority) language (such as Galician) through family transmission in the home or through exposure to its use within the local community, but instead acquired it through the education system or as adult learners, often in the context of language revitalization projects (O'Rourke et al. 2015). Although the mobilization of the term within English-language sociolinguistic research is fairly recent, the concept is rooted in minority language contexts in which speakers, sociolinguistics, and language planners alike have long grappled with the idea of "newness" in relation to languages and their speakers. In the Basque Country, for example, the term euskaldunberri (literally new Basque speaker) already existed as a folk term and is often taken up by sociolinguists and language planners alike to refer this profile of speaker (see Urla 2012). Similarly, in the case of Breton, the term néo-brétonnant (see Hornsby 2015) was frequently used to refer to Breton speakers who acquired the language outside the home. In the Galician context, the term neofalante (literally, 'neo-speaker') had been used to refer to individuals who were brought up speaking Spanish but who made a conscious decision to switch to Galician and in some cases displace their Spanish-speaking persona altogether (see O'Rourke and Ramallo 2013). ${ }^{1}$

The contemporary rise of the 'new speaker' profile in the context of these and other European minority language contexts has in many ways come to represent what O'Rourke et al. (2015) refer to as the "challenging opportunity" facing many European minority languages. This opportunity relates to the fact that new speakers, as a major dimension of minority language revitalization contexts, have the potential to increase the demographic strength of these languages. In many minority language contexts, the number of new speakers is equal to and sometimes surpasses the

\footnotetext{
1 See Boix-Fuster (2009) and Torres (2012) for similar patterns amongst Spanish-speaking parents in Catalonia who make a conscious decision to adopt Catalan language practices with their children.
} 
number of native speakers in the community. We can see this in the context of Manx, for instance, which has no traditional speakers left and where new speakers have become the main lifeline for the language (Ó hIfearnáin 2015). In the case of Irish, there are now more new speakers of the language than native speakers (O'Rourke and Walsh 2015). Similarly, in the Basque Country, younger new speakers are now key players in language activism and language planning initiatives (Ortega 2015). In Galicia, as we will discuss in more detail below, new speakers are bringing Galician into new urban spaces and creating new communities of practice (O'Rourke and Ramallo 2013). Jaffe (2015) describes the emergence of these "new speaker communities" as a sign of optimism and hope after decades of the seeming failure of traditional language revitalization projects. The challenge, however, is whether or not a language can survive without a native speaker community and if the strategies put in place by new speaker parents can re-initiate the process of intergenerational transmission.

\section{New speakers and family language policy}

As in many other parts of the world, in Galicia, traditional native speaker communities have been eroded as a result of economic modernization leading to a break in the intergenerational transmission of the language in the home. While the transmission of the language from one generation of native speakers to the next has for long been considered a crucial part of linguistic vitality (Fishman 2001), recent theorization around new speakers has sought to explicitly question the native speaker ideology in language revitalization movements and (socio)linguistic research more generally (O'Rourke and Pujolar 2013). This questioning can be set against a background in which, over the past two decades in particular, there has been a re-thinking of the Fishmanian model for reversing language shift [see for example, Romaine (2006) and King (2001)]. New speakers, in turn, bring complexity to this paradigm (O'Rourke and Pujolar 2013) and in particular prompt questions about their role as parents and as potential agents of sociolinguistic change in the process of language revitalization. Through their individual as well as collective linguistic practices, new speaker parents have the potential to generate visible and invisible language planning on the ground, influencing their children's language learning and creating future generations of speakers. 'Invisible language planning' has been defined as non-governmental and spontaneous language planning relating to the acquisition and use of a language (Pakir 1994, 2003; Curdt-Christiansen 2009) and may also work as a defence mechanism against the overt language policies introduced by the state (Tannenbaum 2012). As such, through their own linguistic behaviour, new speaker parents can play a potentially significant role in the revitalization and maintenance of a language outside the school through their family language policies in the home.

Although research on bilingual and multilingual families is now well established as an area of enquiry, Family Language Policy (FLP) as a named field, has received most attention in the last decade. In their recent handbook on FLP, Macalister and Mirvahedi (2017) point to the wide range of FLP cases from around the world 
including New Zealand, Uganda, Iran and the USA, which come under the umbrella of FLP. They further underline a number of current requirements in the field, such as being able to examine children's agency and seeing the family as a whole instead of separate individuals. These cases, as they show, bring into focus the multi-layered and multi-sited nature of family dynamics when it comes to decisions about language use and learning, not only within the family itself, but also in their relationship with the wider society. FLP has also become an important area of research in language revitalization studies (see for example, King et al. 2008; Smith-Christmas 2016; Nandi 2018) taking account of the "explicit and overt decisions parents make about language use and language learning as well as implicit processes that legitimize certain language and literacy practices over others in the home" (Fogle 2013: 83). Although initially described as explicit and overt, FLPs can also be de facto, informal and unplanned, as a default consequence of caregivers' ideological beliefs (Curdt-Christiansen 2014). Even in the absence of explicit policy decisions, as Spolsky (2009: 17) points out, "conscious control of the linguistic environment can be considered as an effective method of managing the language socialization of children".

One important direction in FLP within the broader field of language policy has been its framing within the Spolskyian model wherein the focus has been on the intersections between ideologies, management and practice. As Fogle and King (2012: 1) suggest, this framework provides "insights into family language ideology (how family members think about language), language practices (what they do with language) and language management (what they try to do with language)". The ideologies component of the family language policy can include beliefs, attitudes, and norms that describe the value of a language and how it should be used (Armstrong 2012; see also: Kroskrity 2004; Woolard 1998, 2016). Language revival will almost always involve the advancement of a new ideology or ideologies about the value and use of a minoritized language in the face of more dominant, normalized ideologies that support a society's hegemonic language(s) (Tollefson 2015). In this way, language policy can be seen as an expression of the language ideology of an individual or a group with the power to enforce that policy (see for example, Shohamy 2006; Schiffman 2013), which in the context of FLP involves parents or carers. Language ideologies that form the basis of any language policy are manifested through language practice. Therefore, in the family context, individual parents can often be seen to transmit their ideologies through their "language choices in interaction and hence socialize their children into this ideology (...)" (Lanza 2007: 61).

Language planning decisions or "management", on the other hand, have been defined as conscious and explicit efforts by an actor or actors who maintain(s) or intend(s) to exert control over someone in a specific context to modify their language behaviour (Spolsky 2009). Since parents are the in situ language managers in the home, language management at the family level refers to the decisions and attempts that parents make to maintain a language or not and in what form. As Curdt-Christiansen (2014: 38) argues, the distinction between language management and practice inside the home domain "is somewhat blurred as parents may control or intervene in their children's discourse behaviour in their everyday talk". This primarily stems from a shared knowledge that parents are responsible for children's 
language competence (King 2016). Inside the home domain, adult family members often implement a range of monitoring techniques to attain a desired linguistic outcome from the children. Therefore, parental interventions with an intention to correct children's language choices can be considered as one of the most essential tools in determining home linguistic practices. These include various literacy related activities, the selecting of appropriate schools, private tutors and in some cases, peers, to attain a desired linguistic outcome from the children (Nandi and Devasundaram 2017). It thus follows that any analysis that seeks to investigate language policy elements in the home, needs to take into consideration parental beliefs, attitudes, latent ideologies and choices made about language use and the reasons behind those choices (Curdt-Christiansen and Lanza 2018). Moreover, language practices inside the family space underline the systematic and expected linguistic behaviours that establish the de facto language use in various domains and for different purposes (Curdt-Christiansen 2016). De facto everyday language use inside the home domain is essentially different from language ideologies and beliefs since it demonstrates what caregivers really do, instead of what they believe should be done to maintain a language.

In this paper we use the combined lenses of FLP and new speaker research to examine the beliefs, ideologies and choices of new speaker parents as they exercise their agency and enact language policy in the home. While FLP and new speaker research have both gained momentum over recent years, there is relatively little work on FLP and how it plays out amongst new speakers of a minority language. Soler and Zabrodskaja (2017) use the 'new speaker' lens to analyze empirical data collected in Tallinn households among Spanish-Estonian speaking families but focus more specifically on the dynamics of family language policy in the context of transnational multilingual families. Armstrong (2014), on the other hand, provides a more explicit focus on what can be termed "potential" new speakers (see Ramallo and O'Rourke 2014; Carty 2018) in minority language contexts in his study of mothers with children attending Gaelic-medium education, who have to varying degrees learned Scottish Gaelic and who are attempting to create a new language policy in the home. The mothers in Armstrong's study differ to the Galician parents at the centre of the current study, who as will be discussed in more detail below, had already made a conscious decision to adopt Galician as their main language and had in most cases displaced their first language, Spanish, altogether. Their commitment to actively using the minoritized language and to creating new spaces for its use distinguishes them from the broader pool of "potential" new speakers of Galician who acquire the language through the education system but may not yet have taken a leap of faith and make Galician part of their new linguistic repertoire. Ramallo and O'Rourke (2014) note that the majority of Galician new speakers fit into the "potential" category and less than two percent of the population are what can be referred to as "active" new speakers.

While this "active" new speaker profile has received a considerable amount of attention and has been the subject of empirical analysis (in the case of Galician, see O'Rourke and Ramallo 2013, 2015; O'Rourke 2018; for Irish, see O'Rourke and Walsh 2015; for Gaelic, see McLeod and O'Rourke 2015; for Basque, see Ortega 2015), much less attention has been given to the strategies that these speakers 
engage in when bringing up their own children in the minority language. The main contribution of this paper will therefore be to address this gap through an examination of FLP in the context of active new speaker parents. Drawing on two focus group discussions involving seven new speaker families in two of Galicia's urban centres, in what follows we look at the strategies these parents put in place to support a Galician upbringing for their children. To contextualize our data, we will begin with a brief overview of language policies and planning initiatives in contemporary Galicia. This will set the background against which their discourses as both active new speakers and parents can be understood, as they circulate across and within the language policy cycle.

\section{Contextualizing language policy in contemporary Galicia}

Decentralization policies in the context of Spain's transition to democracy in the post-Franco period led to a new legal framework for Galician and the other languages of Spain including Catalan and Basque. This new constitutional status gave co-officiality to Galician along with Spanish within what became the Autonomous Community of Galicia. Working through political and government agencies, an attempt to change the linguistic culture of the time was managed through explicit policy and planning interventions which had major economic, political and cultural consequences (Vila et al. 2016).

Language policy for Galician revolves around what is referred to as Normalización Lingüística (Linguistic Normalization) which promotes the inclusion of Galician in domains from which it came to be historically absent. This includes language policy initiatives in the area of education which supports the progressive incorporation of Galician in the school curricula, with the aim of establishing bilingual programmes in all Galician schools. The education system has produced a large pool of “potential” new speakers (Ramallo and O'Rourke 2014), particularly amongst Spanish-speaking youth in Galicia's cities where Spanish tends to be the most widely used language. Nevertheless, language policy in education is seen to fail in terms of its ability to convert that potential into active use. The overwhelming majority of Galicians under the age of twenty-five say they can speak Galician "well", yet less than half of the same age group report active use of the language. This figure drops to less than one fifth amongst young people living in urban areas (Instituto Galego de Estatística 2014).

Language policy in Galicia has been described as largely non-interventionist and cautionary (Lorenzo-Suárez 2005). This approach reflects the lukewarm levels of support for the promotion of the language by Galician branches of Spain's centreright political parties. Many commentators regard the implementation measures as ineffective (see Regueira 2006; Monteagudo 2012; O'Rourke 2014; Nandi 2017) given that the majority of urban schools in particular failed to meet the stipulated legal requirements set out in Galicia's bilingual educational policy (Silva-Valdivia 2010). The 2007 Decree for the Bilingualism in the education system (Decreto do Bingüismo no sistema educativo) was an attempt to address these policy failings. This Decree was proposed during a brief period of political change in Galicia 
involving a centre-left wing Socialist and Galician Nationalist Party coalition. The Decree sought to ensure that at least fifty percent of school subjects would be imparted in Galician and as such ensuring that existing statutory regulations were adhered to. The proposed amendment did not, however, meet with widespread approval and was the subject of bitter attack from a small but powerful group of a pro-Spanish sector of the Galician population (González-Pascual 2014). This group saw the 2007 proposed amendment as an imposition of Galician and an infringement of their linguistic rights.

The contentious Decree was replaced in 2010 following the return to power of a centre-right wing government who reformulated it as $O$ Decreto do Plurilingüismo (The Decree of Plurilingualism). This advocated for a trilingual model in which one third of the curriculum would be through the medium of Galician with the remaining two thirds in Spanish and English respectively. While the new decree guaranteed the continued presence of Galician in the school system, the stipulated time allocated to the language was further reduced through the addition of English as a third language.

Discontent with these policies has in many ways unsettled the mood of an activist minority of the population (O'Rourke 2014) such as the active new speaker parents at the centre of our study. These speakers constitute a group of individuals who are highly committed to Galician, invest time and energy in the language and commit to using it. These active new speakers, known locally as neofalantes (literally 'neo speakers'), were brought up speaking Spanish in the home but at some stage in their lives (usually adolescence or early adulthood), made a conscious decision to adopt Galician language practices and in some cases, adopt an almost exclusively Galician language repertoire (O'Rourke and Ramallo 2013). These neofalantes are in many ways the product of Galicia's bilingual educational policies described above. However, in becoming active speakers they are also engaging in a reflective process which questions the shortcomings of these policies within existing power structures as well as the socioeconomic and political conditions within which they are set (see O'Rourke 2018)

In the remainder of our paper, we will look at how these active new speaker parents engage in this reflective process. We examine the extent to which official language policy as described above, is contested, negotiated or reproduced by these parents through their own family language policies.

\section{Methodology}

Our study draws on two focus group discussions involving seven families based in two of Galicia's urban centres: Santiago de Compostela and Vigo. All of the families were made up of at least one new speaker parent and in the majority of cases, both parents had new speaker profiles similar to the neofalantes described in O'Rourke and Ramallo (2011, 2013, 2015): they were brought up speaking Spanish in the home, acquired the language through the school system and at some stage in their lives, had made a conscious decision to 'become' active speakers of the language. A variety of reasons were given by participants in the study about the motivations behind such a decision. Some commented on the pivotal role of their 
Galician-speaking partners in their decision to make Galician their main language. Others spoke about the influence of their Galician-speaking parents in decisions to adopt Galician language practices later in life. In contrast, others in the group linked their use of Galician to a more activist stance tied up with their political ideologies and support for Galician nationalism.

Only two families in the study had enrolled their children in the public school system where Galician was a compulsory subject but where Spanish was the main language used by pupils and teachers alike. All other parents had opted for alternative models which went beyond the minimum legal requirements for Galician language provision and instead offered either partial or full immersion in the language. Participants in the study also share many of the socio-demographic and socio-economic characteristics of the neofalantes described in previous research (see O'Rourke and Ramallo 2013), constituting an urban-based, educated, middle-class sector of the population, aged between 35 and 45 years old.

In the discussion groups a series of prompt questions were prepared ahead of the discussions and were drawn upon to stimulate conversation. Participants were told that we were interested in finding out about their experiences as parents who were bringing up their children in Galician. Both discussion groups were conducted through the medium of Galician and each lasted approximately one hour. The discussions were recorded with prior consent of participants and later transcribed. ${ }^{2}$ The discourses from the transcriptions were analyzed and the salient themes explored. We were particularly interested in understanding how these parents perceived their role as transmitters of the language and what collective narrative they were constructing (if any) about their role as language planners on the ground. In what follows, we present extracts which highlight these themes, focusing in particular on the ideologies, management and practices of these parents in framing their Family Language Policy.

\section{Analysis of the data}

\section{Contesting institutional language policy}

Many of the active new speaker parents in the study were openly critical of government policy and objected to the perceived lack of provision for Galician and efforts to promote it. As parents they were, as expected, particularly exercised about language policies in education. Parents across both groups believed that there was insufficient exposure to Galician through the public school system and that the official policy was not leading to competence in the language. While the trilingual model which currently forms part of the national curriculum is not rejected, what parents object to is the unequal distribution of these languages in schools with Spanish occupying the largest proportion of time within the school day. To address this imbalance, they called more explicitly for a Galician-centred model in which

\footnotetext{
${ }^{2}$ In the transcriptions, words which appear in italics designate the use of a Spanish sounding word.
} 
Spanish would be taught as a subject only, in the same way that English is taught. As Adam puts it in Excerpt 1 below:

Excerpt 1

Adam: Eu para min debería ser absolutamente en galego, a: a escola. O castelán, pois as mesmas horas que lle dedican ó inglés, o sea, dúas ou tres horas para reforzalos, para que non cometan erros nas diferencias que hai co galego nas diferencias que hai co galego.
Adam: For me, (the language of school) should absolutely be in Galician. Castilian, well, should be taught the same number of hours as English, I mean, two or three hours just to reinforce them (the languages), so that they (the children) do not make mistakes when it comes to recognising the differences with Galician

Therefore, the suggestion here is that Spanish be taught not as a means in and of itself but as a way of teaching children the differences between Spanish and Galician. Influences from Spanish are referred to as "erros" (mistakes) and as such, as we will also see in the next section below, formed part of a larger discourse around keeping both languages separate and 'pure'.

While there are currently no public schools which offer immersion programmes in Galician, there have been a number of grassroots initiatives which cater for the needs of parents who opt for a Galician-only educational model. Parents based in Santiago, for instance, had enrolled their children in a Galician-only pre-school which functioned as a non-profit association and was funded by parents themselves. Similarly, Dario and Sabela who live in the city of Vigo had opted for an alternative to what was being offered through the public school system and had enrolled their child in a privately-run pre-school which functioned through the medium of Galician and English. While not offering a full Galician immersion experience, for Dario and Sabela, the bilingual Galician-English model was preferable to a Galician-Spanish one:

Excerpt 2

\begin{tabular}{ll}
\hline Dario: En inglés. Entón dixemos, xa, bueno, é & Dario: In English. Then, we said, well, it is better \\
millor que se corrompa, pero (...) & that he is corrupted but (...) \\
Sabela: Pero menos. & Sabela: But less. \\
$\begin{array}{l}\text { Dario: Nunha lingua non..., non necesariamente } \\
\text { cen por cen español }\end{array}$ & $\begin{array}{c}\text { Dario: In a language that is not..., not necessarily } \\
\text { one hundred percent Spanish }\end{array}$ \\
& \\
\hline
\end{tabular}

As can be seen in Excerpt 2 above, Dario's suggestion was that it was better to have his child's Galician "corrupted" by English than by Spanish. Dario's use of the word "corrupt" like Adam's reference to "errors" in the previous excerpt, reflects the anxieties that many of these new speaker parents feel about maintaining boundaries between Galician and Spanish and about the perceived need to carve out what Fishman (1991) refers to as 'breathing spaces' in which Galician is the main language (see O’Rourke (2019) for further discussion) 


\section{Keeping the language pure and speaking 'correct' Galician}

Issues around language purity and correctness such as those discussed above, emerged frequently in both discussion groups, where parents expressed their anxieties not only about their children's shift to Spanish, but also about the use of Spanish structures and Spanish-sounding words in Galician. Parents frequently engaged in language policing and told about the daily battle involved in getting their children to speak "proper" Galician. In the excerpt below, parents talk about "unha pelexa diaria" (a daily battle), "unha batalla terrible" (an awful battle), "unha loita" (a fight) in ensuring that the Galician used by their children is the best it can possibly be:

Excerpt 3

\begin{tabular}{|c|c|}
\hline $\begin{array}{l}\text { Elena: (...) si que é unha pelexa diaria que temos } \\
\text { na casa e por intentar que a lingua deles tamén } \\
\text { sexa o mellor posible non no sentido do vocabu- } \\
\text { lario, senón no sentido tamén das estruturas e, } \\
\text { por exemplo, na colocación [dos pronomes] } \\
\text { Bea: [Dos pronomes] } \\
\text { Elena: Que iso [é] (...) } \\
\text { Adam: [Si] } \\
\text { Elena: [Unha batalla terrible!] } \\
\text { Bea: [É unha loita] } \\
\text { Elena: [Sabes?] Ó principio eu, por exemplo, } \\
\text { co primeiro neno pois cando os colocaba mal, } \\
\text { saltábame, pero agora ás veces con Lola escóitoa } \\
\text { e xa non reparo, non? Aí Virgilio sempre lles } \\
\text { insiste bastante, [non?] } \\
\text { Virgilio: [Si, bueno eu] Como típico neofalante } \\
\text { atrévome a corrixir ós demais, ós meus fillos, } \\
\text { sabes? (risas) }\end{array}$ & $\begin{array}{l}\text { [Elena: (...) yes. It is true that it is a daily struggle } \\
\text { that we have at home and trying to ensure that } \\
\text { their (children's) language is the best it possibly } \\
\text { can be, not only in terms of vocabulary, but in } \\
\text { terms of structure, for instance where to place the } \\
\text { pronouns } \\
\text { Bea: [The pronouns] } \\
\text { Elena: Which is (...) } \\
\text { Adam: [yes] } \\
\text { Elena: [An awful battle!] } \\
\text { Bea: [It is a fight] } \\
\text { Elena: [You know?] In the beginning, for instance, } \\
\text { with my first child I used to correct him instantly } \\
\text { when he used to put the pronouns in the wrong } \\
\text { place, it jumped out at me, but now sometimes } \\
\text { with Lola, I hear it but I don't correct her, you } \\
\text { know? This is one area where Virgilio is always } \\
\text { fairly insistent no? } \\
\text { Virgilio: [Yes, well, I] Like a typical new speaker, } \\
\text { I am not afraid of correcting everyone else, my } \\
\text { children, you know? (laughing)] }\end{array}$ \\
\hline
\end{tabular}

As we can infer from the discussion in this particular excerpt, this group of parents is particularly exercised about the correct use of pronouns in Galician. In Spanish, pronouns come before the verb: Me levanto a las siete (I get up at seven) while in Galician they come after the verb: Levántome ás sete. Spanish-speaking learners of Galician will often make this mistake. Although Elena admits to a softening in her attitude with her second child, she remarks upon the unwavering attitude of her partner, Virgilio, who she says "is always fairly insistent". Virgilio presents this linguistic sanctioning as something which he says is typical of new speakers such as himself, who take it upon themselves to correct everyone else. O'Rourke and Ramallo's (2013) study show that new speakers often demand a high quality of linguistic correctness when it comes to speaking Galician. This, they suggest, may point to a new phase in the process of linguistic revitalization in the Galician sociolinguistic context with a need to "control" the linguistic quality of urban Galician (characteristic of new speakers) (Freixeiro-Mato 2010; Sanmartín Rei 2010). In this new context, certain varieties of urban Galician are given more legitimacy than others. 
As well as grammar policing, parents were equally if not more concerned about vocabulary and in particular the use of Spanish-sounding loanwords in Galician. The following excerpt provides an example of this. Salvador and his wife were bringing up their daughter in Galician. Their family language policy was clear: Galician was the language of the home and every effort was made to ensure that their daughter received an immersion experience in that language and that their input with her was always through the medium of Galician. However, as working parents, Salvador and his wife had enrolled their daughter in childcare outside of the home where Galician was not always or necessarily the language she would hear from her carers or from other children. While Salvador and his wife were all too well-aware of this, they were nevertheless surprised when one day their daughter used the Spanish-sounding word cuchara (spoon) instead of the standard Galician equivalent culler:

\section{Excerpt 4}

\begin{tabular}{|c|c|}
\hline $\begin{array}{l}\text { Salvador: Pois chegou un día que vamos, escoitán- } \\
\text { dolle a primeira palabra esdrúxula, e a primeira } \\
\text { palabra esdrúxula na casa foi corrixíndonos a } \\
\text { nós, logo claro, axiña deducimos que alguén lle } \\
\text { tiña corrixido a ela, non? O sea, nós sempre lle } \\
\text { dicíamos, mira que eso cómese coa culler, non? } \\
\text { Mira, colle a culler, Noelia, tal. "Cu-cha-ra!" } \\
\text { (...) Cu-ller! Que dis? Cu-ller. E ela, "Cu-cha- } \\
\text { ra!" (...) }\end{array}$ & $\begin{array}{l}\text { [Salvador: Well she returned home one day: we } \\
\text { were about to hear her first word using dactylic } \\
\text { stress. The first word with dactylic stress that she } \\
\text { pronounced was to correct us, afterwards, obvi- } \\
\text { ously, we understood that someone has corrected } \\
\text { her (language use) no? I mean, we used to say to } \\
\text { her that this should be eaten with Culler (spoon } \\
\text { in Galician), right? Look, take the culler Noelia. } \\
\text { She said "Cuchara (spoon in Castilian)!" What } \\
\text { are you saying? This is Culler. And she [said], } \\
\text { "Cuchara!" (...)] }\end{array}$ \\
\hline
\end{tabular}

In their attempts to correct her Galician and prompt her to use culler instead of cuchara, Salvador recounts how his daughter pronounced what he in fact erroneously refers to here as "a primeira palabra esdrúxula" (her first ever dactylic stress). She did this by maintaining the first similar sounding syllable $c u$ - from the Galician culler and incorrectly adding two further syllables cha- and $\mathrm{ra}$ - from the Spanish sounding word cuchara. ${ }^{3}$ The Galician word for 'spoon' is culler, but in most Galician dialects (or, rather, sociolects) this word is lost and the Spanish loan word cuchara is used in these cases. The standardization of Galician since the 1980s has attempted to remove such popular Galician forms in an effort to demarcate linguistic boundaries with Spanish (O'Rourke 2017). Linguistic proximity between Galician and Spanish has increased tensions around the need to maintain distance between

\footnotetext{
3 A dactylic stress is a three-syllable metrical pattern in poetry in which a stressed syllable is followed by two unstressed syllables. In English, the word "poetry" itself is an example of a dactylic stress, with the stressed syllable falling on the "Po," followed by the unstressed syllables "e" and "try": Po-e-try. Whereas the Spanish word cu-cha-ra with the stressed syllable falling on "cu" is an example of dactylic stress, culler is not. Instead it is a paroxytone word with stress on the penultimate syllable $\mathrm{cu}$-ller. Notably, although many Castilian words maintain a dactylic stress, their Galician counterparts are pronounced as paroxytone. For instance, the Castilian word for bird is pájaro (pá-ja-ro) and Galician word for the same is paxaro (pa-xa-ro) with stress on "xa". However, many Galicians including the new speakers tend to pronounce it as páxaro due to Castilian's hegemonic presence in their everyday speech pattern (see Regueira 2010).
} 
the two varieties. This is driven by fears about crossing too far over the language divide, set against a background in which blurring between the two varieties has historically justified the socio-politically motivated process of what Kloss (1967) refers to as "dialectalization". At various moments in the sociolinguistic history of Galician, the language was regarded as a sub-standard variety of Spanish (Monteagudo 1999).

Salvador's sanctioning of his daughter's use of this Spanish loan word is likely to be linked to his own anxieties around the need to set out clear boundaries between Spanish and Galician. These tensions resonate with similar scenarios in other parts of the world where language planners and activists are faced on the one hand with recognizing the value of mixed or plural identities but where there is also a clear attempt to escape relations of dominance which places a high a price on declarations of absolute difference and clear-cut boundaries (Jaffe 1993:101). Ironically, Salvador, in his attempt to ensure that his daughter's Galician is kept pure and intact, is in fact replicating the dominant Spanish-only ideology which he and other activist parents are at pains to supress. Salvador's assumption is that his daughter's use of the Spanish loan word is a result of external reprimands outside of the home, stating unequivocally: deducimos que alguén lle tiña corrixido a ela, non? (we deduced that someone had corrected her, no?). However, this may in fact be an erroneous assumption and the possibility also exists that she picked up the word from a Galician speaker who resorted to cucharra not as a Spanish word but as a Galician word from within his or her dialectal variation.

\section{Galician as deviant or out of place}

While institutional support for Galician since the 1980s promotes the inclusion of the language in public domains and facilitates its greater social presence, urban spaces continue to be largely Spanish-speaking and in such contexts, Spanish tends to be the norm and unmarked linguistic code. As such the use of Galician in urban spaces is sometimes seen as out of place or deviant. Previous studies (see O'Rourke and Ramallo 2013) point to the difficulties that urban new speakers see themselves as having when it comes to changing their linguistic behaviour and in becoming Galician speakers. This singling out of new speakers as being different or in some way special denies them the invisibility and anonymity of "just talk" in Woolard's $(2008,2016)$ terms associated with the use of Spanish. Many of the new speaker parents in the current study also report feeling out of place or having their own linguistic behaviour brought into question. One parent for example, reported her failed attempts to switch to Galician in her adolescence because such linguistic behaviour was seen as strange, leading to questions such as: “¿y ahora cómo se te dá por ahí? (why is it that you are doing that?). It was only later on, when she had more 
confidence in herself and conviction in her decisions as a young adult at university, that she took the leap of faith and adopted Galician as her main language.

As parents, these new speakers also felt they needed to justify their decision to raise their own children in Galician. As one parent put it:

Excerpt 5

Inma: Eu son neofalante que tódolos días me esforzo duramente por manter o galego... que lle falo galego ós meus fillos $i$ que teño que escoitar que como son do BNG $i$ no se qué, politizo o tema da lingua
[Inma: I am a new speaker and I make a huge effort every day to maintain Galician... so that I can speak Galician with my children and I have to lis- ten to [commentary] that because I am a supporter of the Galician Nationalist Party and whatever, I am politicising the language question

In the extract above, Irma talks about the efforts she makes as a new speaker to maintain Galician and to speak the language with her children. However, her sense is that not only are these efforts not recognized but she is subjected to commentary which perceive her support for the language as linked to the politics of Galician nationalism. This perception is often fed by left-wing nationalists themselves, with an essentialist discourse of language as a symbol of national identity and as such, making Galician a central component of their political ideology. While not all new speakers are necessarily supporters of this political party, the stereotype exists and for urban Spanish-speaking groups, new speakers' switches to Galician can have a very clear meaning: that they are language activists and supporters of Galician nationalism (O'Rourke 2011: 141). Similar to other minority language contexts, we see therefore an overpolitization of communicative activity (Jaffe 1999: 246). This explains why many of the parents in the group were concerned about the difficulty in finding 'safe spaces' in which to use the language, spaces in which their use of Galician would not be questioned and where speaking Galician would be seen as the norm. Sabela's story in the excerpt below highlights this concern. Here she shares her account of an occasion when her 3-year-old daughter was playing with other children and was she claims, ridiculed by a group of older girls for speaking Galician:

\section{Excerpt 6}

\begin{tabular}{lc}
\hline Sabela: (...) houbo un momento no que estaba & [Sabela: (...) there was a moment when she was \\
xogando nun parque de bólas cunhas nenas & playing in a ball pit with some older girls, who \\
maiores, non? Que tiñan así como sete anos, & were around seven or eight years old. Then, I saw \\
oito anos e tal. Entón, vin que... e houbo & that... and there was a moment when they said to \\
un momento que lle dicían "ay, y tú hablas & her "and do you speak Galician?" mocking her, \\
galeguiño?" Como xa vacilando, ¿non? A miña & you know (for speaking Galician). Right? My \\
filla así "si, eu falo galego, si ¿por qué?" & daughter said "yes, I speak Galician, yes. Why?" \\
Dario: Pero é unha inconsciencia, porque a nosa & Dario: But, there is no awareness, because our \\
nena [aínda non é consciente con tres anos das & daughter [she is not yet aware of the circum- \\
circunstancias] & stances as she is only 3 years old] \\
Sabela: [Efectivamente, claro, claro.] & Sabela: [Indeed, of course] \\
César: [Claro.] & César: [Of course.] \\
Sabela: Efectivamente. No, no, claro. Evidente- & Sabela: Indeed, of course she is not. She will speak \\
mente aí vai falar castelán (...) & Castilian for sure \\
Paloma: Claro, eso $(. .)$. & Paloma: Indeed, that's it
\end{tabular}


In the telling of her story, Sabela switches to Spanish to reproduce the question that the girls seemingly had asked of her daughter: "ay, y tú hablas galeguiño?" (ah, and do you speak Galician?). The word galeguiño contains the word galego (Galician) and the frequently used diminutive -iño/-iña [corresponding to -ito/-ita in Spanish]. This diminutive is often used to mark affection but here its use is perceived by Sabela as pejorative and condescending of her daughter's use of Galician. The Galician -iño/-iña is often used in Galician Spanish and can sometimes be used mockingly in stereotypical impressions of how Galicians sound to people from other parts of Spain. While Sabela says that her daughter is probably too young to be aware of what is going on in this situation, as she gets older and starts to realize what all of this means, Sabela and others in the group predict that these types of situations will prompt her to eventually switch to Spanish. Therefore, despite the efforts of parents such as Sabela to invest in the language and to create a Galicianspeaking environment for their children, outside of these spaces, Spanish remains the more valued language.

This situation in turn often prompts new speaker parents, to create their own spaces in order to support the use of Galician for their children. Many of the parent in the group had been involved in the setting up a WhatsApp group which they called Tribo ('Tribe' in Galician). Initiated in the summer of 2013, Tribo comprised more than 40 families who would meet several times a week to enable their children to socialize and converse in Galician (Bal and Rodríguez 2014). Many of the new speaker families involved in our study were at the time active members of this group. Parents interested in joining the collective could contact the group members though the technological interface. They could also communicate informally amongst themselves, meeting in different places in Santiago to organize or participate in various extracurricular or cultural activities that involved their children interacting together in Galician. Tribo's main aim, as the group explained, was to create a Galician-speaking space for urban-based families who were bringing up their children in Galician but who found it difficult to find spaces in which Spanish was not the dominant language.

\section{Concluding remarks}

In determining the survival prospects of minority languages such as Galician, earlier studies on language maintenance and shift often implicated macro-social events as direct causes of survival or decline (see Weinreich 1968). However, later research has highlighted that it is only through an analysis of the interpretative filter of beliefs about language that the effects of macrosocial factors can be assessed (Mertz 1989: 109). Similarly, in language policy research, the contrasting divides between 'topdown' and 'bottom-up' policies, have been replaced by analyses of how discourses circulate across and within the language policy cycle (Canagarajah 2006). Our discussion in this paper has been set within this framework, with a focus on how social actors position themselves vis-à-vis the different discourses in circulation and as such opening up ideological spaces for the use or non-use of certain languages or linguistic varieties. Our interest has been in understanding how macro-level policies 
are interpreted, implemented and negotiated by social actors on the ground. In this paper we looked specifically at how official language policies in contemporary Galicia are interpreted and negotiated by new speaker parents who have made a conscious decision to bring up their children in Galician, a language which they themselves did not acquire in the home. Through their individual as well as collective linguistic practices, we have argued that these new speakers act as both visible and invisible language planners and can influence their children's attitudes towards a minority language such as Galician as well as their desire to learn and speak it.

Galician is taught in all government funded schools in Galicia and all schools are officially bilingual in Spanish and Galician. In practice, however, as we have set out above, the number of subjects taught in Galician varies depending on the language of the students and language preference of the teacher and parents. In urban areas, in particular, where there is a predominance of Spanish, the amount of Galician used in school can be low. This poses both a practical and policy problem in promoting minoritized languages such as Galician: firstly, how are new norms for the use of a potentially threatened language established in a given site and secondly, how can these norms be defended against the counter-ideology of a dominant language in which a language such as Spanish continues to be the norm? The new speaker parents who participated in our study were deeply concerned with the fact that their own children and children of others they knew were not getting sufficient Galician input through Galicia's public education system. Many of these parents were urban based new speakers of Galician themselves who had not been brought up speaking the language in the home but had made a conscious decision to bring up their children in Galician and as such, play their part in reversing intergenerational transmission. In doing so, new speaker parents in Santiago and Vigo were making language planning or "management" decisions about their children's language practices. They were making very conscious and explicit efforts to exert control over their children's language behaviours and at times to modify the forms of language which they used. In their role as language managers in the home, they seemed to engage in explicit attempts to not only maintain Galician but to maintain a very specific type of Galician which was free from Spanish loanwords and the use of what they considered 'correct' Galician. Parents in the group took responsibility for their children's language competence which they believed was not been achieved through the public-school system and thus opted for an alternative model in which Galician played an exclusive or predominant role. Parents implemented a range of monitoring techniques to attain the desired linguistic outcome from the children. These included language policing such as an emphasis on grammatical correctness and the correcting of Spanish loan words. Such strategies were not always successful, and children sometimes resisted or ignored their parent's efforts to impose a particular language or way of using it. Parents recognized that despite their efforts, it was difficult to escape dominant language ideologies in which Spanish continued to be recognized as the unquestioned norm outside of the Galician-friendly home spaces they had attempted to create. Their Family Language Policy centred around establishing 'safe spaces' for their children which allowed for greater exposure to the language than was in their eyes being offered through official language policies. 
However, a recurrent concern for these new speaker parents was that the 'safe spaces' which they tried so hard to create for their children, despite their efforts, were nonetheless 'diluted' with Spanish. Thus, in their attempts to escape relations of dominance, they struggled, on the one hand, with recognizing the plurality of identities in Galician society and translingual practices that this produced and on the other, with setting up clear-cut boundaries to 'protect' what they saw as a threatened language and culture. New speakers such as those examined in this study often consciously invest in language separation. This is contrary to new trends in sociolinguistic research which advocate for fluid language and a criticism of Fishmanian language revitalization models. However, while investing in language separation is not without problems, as McCarty (2018: 472) points out, context matters and through their grass-roots decisions about what is meaningful for their own situated practices, these new speaker Galician parents play an important part in shaping language policy on the ground.

Acknowledgements This work was supported by the European Cooperation in Science and Technology as part of EU COST Action IS1306 entitled 'New Speakers in a Multilingual Europe: Opportunities and Challenges'. We would also like to acknowledge funding for the Sustaining Minoritized Languages in Europe (SMiLE) project supported by the Smithsonian Centre for Folklore and Cultural Heritage. The paper builds on a larger project, funded as part of an Arts and Humanities Research Council (UK) Fellowship for the project 'New Speakers of Minority Languages and their role in Linguistic Revitalisation' (Grant number AH/J00345X/1).

Open Access This article is distributed under the terms of the Creative Commons Attribution 4.0 International License (http://creativecommons.org/licenses/by/4.0/), which permits unrestricted use, distribution, and reproduction in any medium, provided you give appropriate credit to the original author(s) and the source, provide a link to the Creative Commons license, and indicate if changes were made.

\section{References}

Armstrong, T. C. (2012). Establishing new norms of language use: The circulation of linguistic ideology in three new Irish-language communities. Language Policy, 11, 145-168.

Armstrong, T. C. (2014). Naturalism and ideological work: How is family language policy renegotiated as both parents and children learn a threatened minority language? International Journal of Bilingual Education and Bilingualism, 15(5), 570-585.

Bal, R., \& Rodríguez, I. (2014). Pais e profesionais organízanse para impulsar o ensino en galego. 06 March 2014. http://www.galiciaconfidencial.com/noticia/17979-pais-profesionais-organizans e-impulsar-ensino-galego. Accessed June 19, 2018.

Baldauf, R. B., Jr. (2006). Rearticulating the case for micro language planning in a language ecology context. Current Issues in Language Planning, 7(2), 147-170.

Boix-Fuster, E. (2009). Català o castellà amb els fills? La transmissió de la llengua en families bilingües a Barcelona. Barcelona: Rourich.

Canagarajah, S. (2006). Ethnographic methods in language policy. In T. Ricento (Ed.), An introduction to language policy: Theory and method (pp. 153-169). Oxford: Wiley Blackwell.

Carty, N. (2018). New speakers, potential new speakers, and their abilities in Scottish Gaelic. In C. Smith-Christmas, N. P. Ó. Murchadha, M. Hornsby, \& M. Moriarty (Eds.), New speakers of minority languages: Ideologies and practices (pp. 253-270). Basingstoke: Palgrave MacMillan.

Curdt-Christiansen, X. L. (2009). Visible and invisible language planning: Ideological factors in the family language policy of Chinese immigrant families in Quebec. Language Policy, 8(4), 351-375. 
Curdt-Christiansen, X. (2014). Family language policy: Is learning Chinese at odds with learning English? In X. Curdt-Christiansen \& A. Hancock (Eds.), Learning Chinese in diasporic communities (pp. 35-55). Amsterdam: John Benjamins.

Curdt-Christiansen, X. L. (2016). Conflicting language ideologies and contradictory language practices in Singaporean bilingual families. International Journal of Multilingual and Multicultural Development, 37(7), 694-709.

Curdt-Christiansen, X., \& Lanza, E. (2018). Language management in multilingual families: Efforts, measures and challenges. Multilingua, 37(2), 123-130. https://doi.org/10.1515/multi-2017-0132.

Fishman, J. (1991). Reversing language shift. Clevedon:Multilingual Matters.

Fishman, J. A. (2001). Can threatened languages be saved? Clevedon: Multilingual Matters.

Fogle, L. W. (2013). Parental ethnotheories and family language policy in transnational adoptive families. Language Policy, 12(1), 83-102.

Fogle, L. W., \& King, K. A. (2012). Child agency and language policy in transnational families. Issues in Applied Linguistics, 19, 1-25.

Freixeiro-Mato, X. R. (2010). Galician as a threatened language: the process of linguisticsubstitution in Galicia. Arena romanística, 6, 208-231.

González-Pascual, I. (2014). La ideologia lingüística contrària a la revitalització del gallec. El cas de Galicia Bilingüe. Treballs de Sociolingüística Catalana, 24, 201-224.

Hornsby, M. (2015). Revitalizing minority languages new speakers of Breton, Yiddish and Lemko. Basingstoke: Palgrave.

Instituto Galego de Estatística. (2014). Enquisa de Condicións de Vida das Familias. Coñecemento e Uso do Galego. Ano 2013. Santiago de Compostela: Instituto Galego de Estatística (IGE). www.ige.eu. Accessed June 18, 2018.

Jaffe, A. (1993). Talk around text: Literacy practices, cultural identity and authority in a corsican bilingual classroom. International Journal of Bilingual Education and Bilingualism, 6(3-4), 202-220.

Jaffe, A. (1999). Ideologies in action: Language politics on Corsica. Berlin:Mouton de Gruyter.

Jaffe, A. (2015). Defining the new speaker: Theoretical perspectives and learner trajectories. International Journal for the Sociology of Language, 231, 21-44.

Johnson, D. (2013). Language policy. London: Palgrave Macmillan.

King, K. A. (2001). Language revitalization: Processes and prospects-Quichua in the Ecuadorian Andes (Vol. 24). Clevedon: Multilingual Matters.

King, A. K. (2016). Language policy, multilingual encounters, and transnational families. Journal of Multilingual and Multicultural Development, 37(7), 726-733.

King, K. A., Fogle, L., \& Logan-Terry, A. (2008). Family language policy. Language and Linguistics Compass, 2(5), 907-922.

Kloss, H. (1967). 'Abstand languages' and 'Ausbau languages'. Anthropological Linguistics, 9(7), $29-41$.

Kroskrity, P. (2004). Language ideology. In A. Duranti (Ed.), Companion to linguistic anthropology (pp. 496-517). Oxford: Blackwell.

Lanza, E. (2007). Multilingualism and the family. In P. Auer \& L. Wei (Eds.), Handbook of multilingualism and multilingual communication (pp. 45-66). Berlin: Mouton de Gruyter.

Lorenzo-Suárez, A. M. (2005). Planificación lingüística de baixa intensidade: O caso Galego. Cadernos de Lingua, 27, 37-59.

MacAlister, J., \& Mirvahedi, S. (2017). Family language policies in a multilingual world: Opportunities, challenges, and consequences. Oxon: Routledge.

McCarty, T. L. (Ed.). (2011). Ethnography and language policy. New York: Routledge.

McCarty, T. (2018). Comparing 'new speakerhood': Context, positionality, and power in the new sociolinguistic order. Journal of Multilingualism and Multilingual Development, 39, 470-474.

McLeod, W., \& O’Rourke, B. (2015). 'New speakers' of Gaelic: Perceptions of linguistic authenticity and appropriateness. Applied Linguistics Review, 6, 151-172.

Mertz, E. (1989). Sociolinguistic creativity: Cape Breton Gaelic's linguistic "tip". In N. C. Dorian (Ed.), Investigating obsolescence. Studies in language contraction and death (pp. 103-116). Cambridge: Cambridge University Press.

Monteagudo, H. (1999). Historia social da lingua galega. Vigo: Galaxia.

Monteagudo, H. (2012). Política lingüística en Galicia: Apuntes para un nuevo balance. In G. Kremnitz, P. Cichon, \& B. Czernilofsky-Basalka (Eds.), Quo vadis, Romania (pp. 21-39). Wien: Institut für Romanistik, Universität Wein.

Nandi, A. (2017). Language policies and linguistic culture in Galicia. LaborHistórico, 3(2), 28-45. https ://doi.org/10.24206/lh.v3i2.17124. 
Nandi, A. (2018). Parents as stakeholders: Language management in urban Galician homes. Multilingua, 37(2), 201-223. https://doi.org/10.1515/multi-2017-0020.

Nandi, A., \& Devasundaram, A. I. (2017). Contesting the conventionalising of Castilian: The Role of Galician parents as counter-elites. In F. Lauchlan \& M. C. Parafita-Couto (Eds.), Bilingualism and minority languages in Europe: Current trends and developments (pp. 12-33). Newcastle Upon Tyne: Cambridge Scholars Publishing.

Ó hIfearnáin, T. (2015). Sociolinguistic vitality of Manx after extreme language shift: Authenticity without traditional native speakers. International Journal of the Sociology of Language, 2015(231), 45-62.

O'Rourke, B. (2011). Galician and Irish in the European context: Attitudes towards weak and strong minority languages. Basingstoke: Palgrave Macmillan.

O'Rourke, B. (2014). The Galician language in the twenty-first century. In H. Miguélez-Carballeira (Ed.), A companion to Galician culture (pp. 73-92). Woodbridge: Tamesis.

O'Rourke, B. (2017). Competing ideologies of authority and authenticity in the global periphery. In P. Lane, J. Costa, \& H. De Korne (Eds.), Standardizing minority languages (pp. 84-100). Oxon: Routledge.

O'Rourke, B. (2018). Just use it! Linguistic conversion and identities of resistance amongst Galician new speakers. Journal of Multilingual and Multicultural Development, 39(5), 407-418. https://doi. org/10.1080/01434632.2018.1429455.

O'Rourke, B. (2019). Carving out breathing spaces for Galician: New speakers' investment in monolingual practices. In J. Jaspers \& L. M. Madsen (Eds.), Critical perspectives on linguistic fixity and fluidity: Languagised lives. New York/London: Routledge.

O'Rourke, B., \& Pujolar, J. (2013). From native speakers to "new speakers"-Problematizing nativeness in language revitalization contexts. Histoire Épistémologie Langage, 35(2), 47-67.

O'Rourke, B., \& Ramallo, F. (2011). The native-non-native dichotomy in minority language contexts comparisons between Irish and Galician. Language Problems and Language Planning, 35(2), 139-159.

O’Rourke, B., \& Ramallo, F. (2013). Competing ideologies of linguistic authority amongst newspeakers in contemporary Galicia. Language in Society, 42, 287-305.

O'Rourke, B., \& Ramallo, F. (2015). Neofalantes as an active minority: Understanding language practices and motivations for change amongst new speakers of Galician. International Journal for the Sociology of Language, 231, 147-165.

O'Rourke, B., \& Walsh, J. (2015). New speakers of Irish: Shifting boundaries across time and space. International Journal of the Sociology of Language, 231, 63-83.

O'Rourke, B., Pujolar, J., \& Ramallo, F. (2015). New speakers of minority languages: the challenging opportunity - Foreword. International Journal for the Sociology of Language, 231, 1-20.

Ortega, A., Urla, J., Amorrortu, E., Goirigolzarri, J., \& Uranga, B. (2015). Linguistic identity among new speakers of Basque. International Journal for the Sociology of Language, 231, 85-105.

Pakir, A. (1994). Education and invisible language planning: The case of English in Singapore. In T. Kandiah \& K. Kwan-Terry (Eds.), English language planning: A southeast Asian contribution (pp. 158-181). Singapore: Centre for Advanced Studies and Times Academic Press.

Pakir, A. (2003). Language and education: Singapore. In J. Bourne \& E. Reid (Eds.), World yearbook of education: Language education (pp. 267-279). London: Kogan Page Publisher.

Ramallo, F., \& O'Rourke, B. (2014). Profiles of new speakers of Galician. Digithum, no. 16. https://www. raco.cat/index.php/Digit/article/viewFile/304441/394160. Accessed June 13, 2018.

Regueira, X. L. (2006). Política y lengua en Galicia: La ‘normalización’ de la lengua gallega. In M. Castillo-Lluch \& J. Kabatek (Eds.), Las lenguas de España. Política lingüística, sociología del lenguaje e ideología desde la Transición hasta la actualidad (pp. 61-93). Madrid/Frankfurt am Main: Iberoamericana/Vervuert.

Regueira, X. L. (2010). Dicionario de pronuncia da lingua galega. A Coruña: Real Academia Galega. Retrieved from http://ilg.usc.es/pronuncia.

Ricento, T. (2015). Foreword. In F. M. Hult \& D. Johnson (Eds.), Research methods in language policy and planning: A practical guide (pp. xii-xv). West Sussex: Wiley Blackwell.

Romaine, S. (2006). Planning for the survival of linguistic diversity. Language Policy, 5(2), 443-475.

Sanmartín Rei, G. (ed.) (2010). Lingua e futuro. A Coruña: Laiovento.

Schiffman, H. (2013). Language policy and multilingualism. In C. A. Chapelle (Ed.), The Encyclopedia of applied linguistics (pp. 3084-3092). Oxford: Wiley-Blackwell. 
Shohamy, E. (2006). Language policy: Hidden agendas and new approaches. London, New York: Routledge.

Silva-Valdivia, B. (2010). Máis competentes en castelán que en galego. Tempos Novos, 158, $43-47$.

Smith-Christmas, C. (2016). Family language policy: Maintaining an endangered language in the home. Basingstoke: Palgrave Macmillan.

Soler, J., \& Zabrodskaja, A. (2017). New spaces of 'new speaker' profiles: Exploring language ideologies in transnational multilingual families. Language in Society, 46, 547-566.

Spolsky, B. (2009). Language management. Cambridge, New York: Cambridge University Press.

Tannenbaum, M. (2012). Family language policy as a form of coping or defense mechanism. Journal of Multilingual and Multicultural Development, 33(1), 57-66.

Tollefson, J. W. (2015). Language education policy in late modernity: Insights from situated approaches-commentary. Language Policy, 14(2), 183-189.

Torres, J. (2012). L'evolució dels usos privats a Catalunya del 1997 al 2008. Treballs de Sociolingüística Catalana, 22, 27-40. https://doi.org/10.2436/20.2504.01.40.

Urla, J. (2012). Reclaiming basque: Language, nation, and cultural activism. Reno: University of Nevada Press.

Vila, X., Lasagabaster, D., \& Ramallo, F. (2016). Bilingual education in the autonomous regions of Spain. In O. Garcia, A. M. Y. Lin, \& S. May (Eds.), Bilingual and multilingual education, Encyclopedia of language and education. Basel: Springer. https://doi.org/10.1007/978-3-319-02324-3_28-1.

Weinreich, U. (1968). Languages in contact: Findings and problems. The Hague: Mouton.

Woolard, K. A. (1998). Introduction: Language ideology as a field of inquiry. In B. B. Schieffelin, K. A. Woolard, \& P. V. Kroskrity (Eds.), Language ideologies: Practice and theory (pp. 3-47). Oxford: Oxford University Press.

Woolard, K. A. (2008). Language and identity choice in Catalonia: The interplay of contrasting ideologies of linguistic authority. In K. Süselbeck, U. Mühlschlegel, \& P. Masson (Eds.), Lengua, nación e identidad. La regulación del plurilingüismo en España y América Latina (pp. 303-324). Madrid: Iberoamericana Vervuert.

Woolard, K. A. (2016). Singular and plural ideologies of linguistic authority in 21st century Catalonia. Oxford: Oxford University Press.

Bernadette O'Rourke is Professor of Sociolinguistics in the School of Social Sciences at Heriot-Watt University (UK). She was Chair of COST Action 1S1306 "New Speakers in a Multilingual Europe: Opportunities and Challenges" (2013-2017). Her research focuses on the intersection between language and society in multilingual contexts. She is author of Galician and Irish in the European Context (Palgrave, 2011) and co-author of the Handbook of Minority Languages and Communities (Palgrave, 2019). She will take up a Professorship at the University of Glasgow from April 2019.

Anik Nandi is a Postdoctoral Research Fellow at the School of Arts, English and Languages of Queen's University Belfast, Northern Ireland (UK). He is also an external collaborator at the Sociolinguistic Seminar of the Royal Galician Academy, Galicia (Spain). Anik's research interests centre primarily on language policy, ethnography and critical discourse analysis. 